\title{
Stratospheric ozone: down and up through the anthropocene
}

\author{
Ulrike Langematz ${ }^{1}$
}

Received: 21 December 2018 / Accepted: 14 February 2019 / Published online: 23 April 2019

(c) The Author(s) 2019

\begin{abstract}
The stratospheric ozone layer protects life on Earth by absorbing harmful ultraviolet (UV) radiation from the sun. The spatial and temporal distribution of stratospheric ozone is determined by chemical and dynamical processes. Maximum ozone mixing ratios are found in the tropical middle stratosphere as the result of photochemical processes involving oxygen. From its tropical production region ozone is then transported to higher latitudes by the meridional circulation. In addition, ozone is destroyed in catalytic chemical cycles involving reactive, so-called ozone depleting substances (ODSs). These ODSs include chlorine, bromine, hydrogen and nitrogen compounds from source gases emitted at Earth's surface by industry and transported into the stratosphere. With increasing production and consumption of ODSs since the 1970s stratospheric ozone began to decline globally. Due to a combination of cold meteorological conditions and specific chemical reactions, the ozone hole developed over Antarctica each springtime since the early 1980s. In a tremendous effort, scientists, politicians and industry managers responded to this threat to the ozone layer. In 1987, the Montreal Protocol was accepted by the member states of the United Nations. The regulations of ODSs defined by the Montreal Protocol and its Amendments and adjustments ultimately led to a turning point of ozone depletion and a slow recovery of stratospheric ozone since the 2000s. This article provides the background of ozone chemistry and dynamics and reviews anthropogenic ozone depletion in the past as well as recent model projections of future ozone recovery and its interaction with climate change.
\end{abstract}

Keywords Ozone $\cdot$ Stratosphere $\cdot$ Chemistry $\cdot$ Climate $\cdot$ Numerical models

\section{Introduction}

Ozone, the three-atomic form of oxygen (chemical formula: $\mathrm{O}_{3}$ ), is a minor gas naturally present in Earth's atmosphere. About $90 \%$ of the atmospheric ozone resides in the lower to middle stratosphere between about 15 and $35 \mathrm{~km}$ altitude (often referred to as the "ozone layer"), while only $\sim 10 \%$ are found in the troposphere (Fig. 1). Near Earth's surface, increases in ozone are due to man-made air pollution. Although the maximum mixing ratio of ozone is in the range of only ten molecules per one million air molecules, stratospheric ozone is of tremendous importance for life on Earth. It is assumed that the evolution of life on the continents was only possible after the atmospheric ozone layer had developed. By absorbing a large part of the biologically harmful UV-B radiation from the sun, stratospheric ozone

Ulrike Langematz

ulrike.langematz@met.fu-berlin.de

1 Institut für Meteorologie, Freie Universität Berlin, Carl-Heinrich-Becker-Weg 6-10, 12165 Berlin, Germany protects life on Earth against health risks, such as skin cancer or cataracts, as well as biological damages of terrestrial plants and aquatic ecosystems. In contrast, high ozone levels near Earth's surface caused by air pollution are harmful to humans and living systems in general, as they may induce heart and lung problems and reduce plant growth and crop yields. The focus of this article is on stratospheric ozone. The chemical and dynamical processes that determine stratospheric ozone concentrations will be discussed, as well as the changes in stratospheric ozone abundance due to anthropogenic impacts in the past and future.

\section{A brief history of ozone}

Ozone was discovered in 1839 by the German chemist and professor at the University of Basel, Christian Friedrich Schönbein (Fig. 2). He had noticed an intense odour during experiments with the electrolysis of water and named the unknown smelling substance "ozone" after the Ancient Greek word oל̌ıı (ozein: to smell). Schönbein developed a 


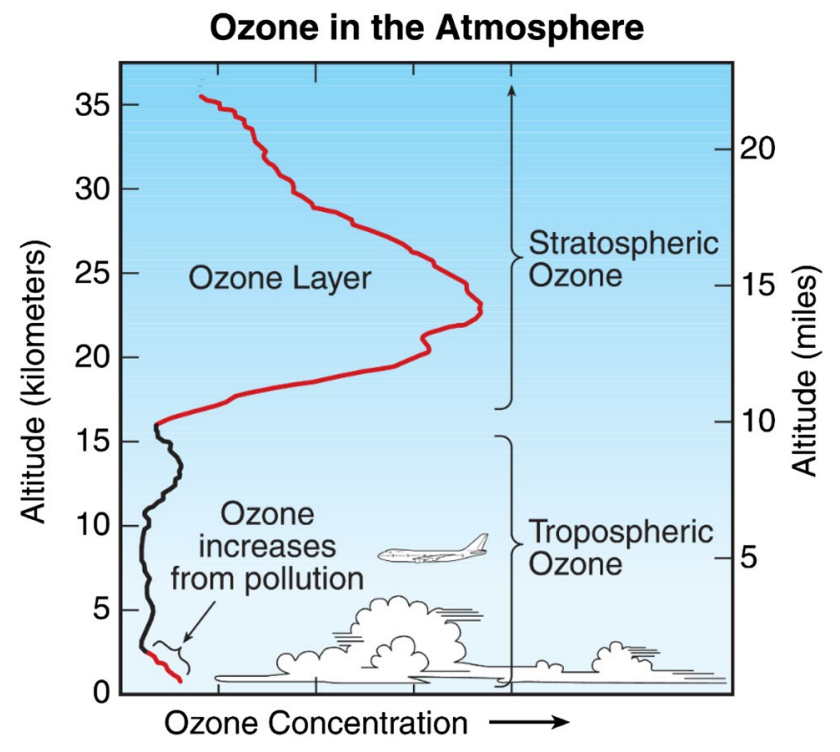

Fig. 1 Vertical ozone profile. Most ozone resides in the stratospheric "ozone layer". Increases in ozone near the surface are a result of pollution from human activities (from [1])

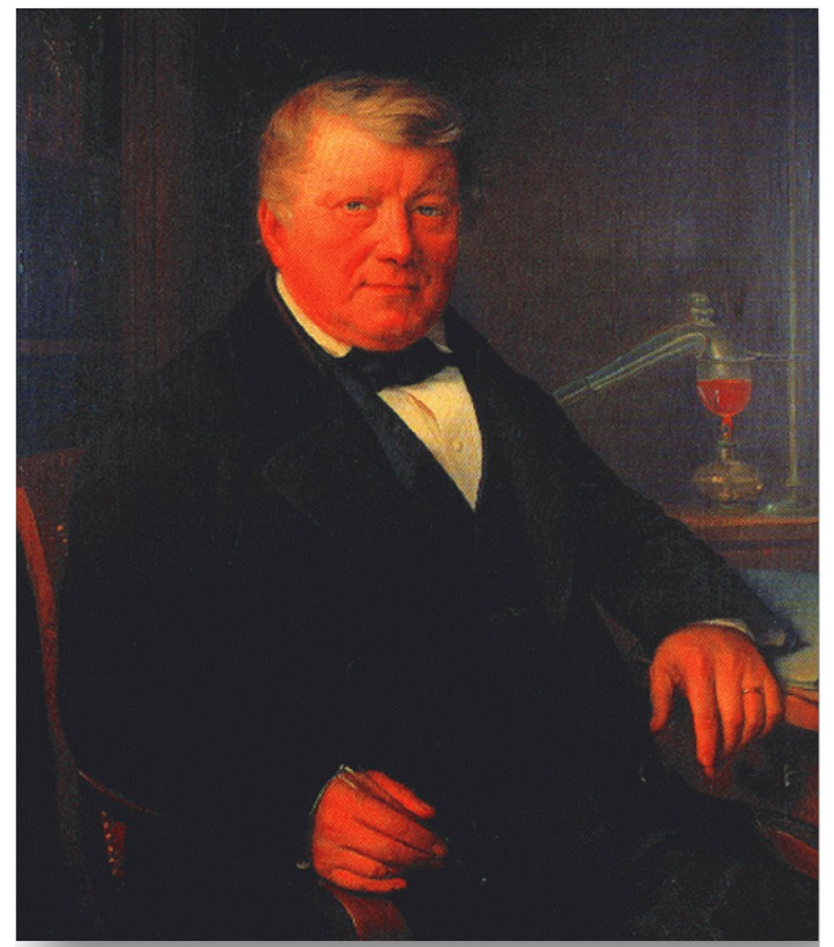

Christian Friedrich Schönbein, 1799-1868

Naturhistorisches Museum (Basel)

Fig. 2 Portrait of Christian Friedrich Schönbein in the Naturhistorisches Museum Basel, painted by Heinrich Beltz in 1857

first chemical method to measure ozone which based upon the nature of potassium iodide to chemically react with ozone. Ozone concentrations were derived by comparing the change of the blue tone of a sheet of paper covered with potassium iodide in the presence of ozone with the Schönbein Scale. Through the second half of the nineteenth century, first measurements from a small network of European sites (i.e. Vienna, Emden, Paris) revealed that ozone was a permanent chemical constituent of the atmosphere. Using optical instruments to measure the solar spectral irradiance, Sir Walter Hartley concluded in 1880 that the strong absorption of solar UV radiation between 200 and $320 \mathrm{~nm}$, which had been discovered by Marie Alfred Cornu 2 years before, is produced by ozone and that, therefore, larger amounts of ozone exist permanently in the upper atmosphere [2]. His findings were supported later in UV measurements by Charles Fabry and Henry Buisson who derived an atmospheric ozone abundance of $5 \mathrm{~mm}$ (500 Dobson Units, DU) from their measurements [3]. At about the same time, James Chappuis discovered the ozone absorption in the visible part of the solar spectrum $(500-700 \mathrm{~nm}$ ), followed by Sir William Huggins 10 years later who measured the ozone absorption lines between 310 and $360 \mathrm{~nm}$. A further milestone in stratospheric ozone research was the construction of a series of UV-spectrophotometers by Sir Gordon Miller Bourne Dobson in the 1920s [4]. These instruments not only provided new insights in the geographical and seasonal distribution of the ozone column but also allowed, in conjunction with the Umkehr method of F.W. Paul Götz, to retrieve information of the vertical ozone profile. The altitude of the ozone maximum at about $22 \mathrm{~km}$ derived from the Umkehr method [5] was supported by first in- situ spectroscopic measurements from balloons in Germany by Erich and Victor H. Regener in 1934 and the Explorer II mission in the USA 1 year later.

\section{Factors determining the ozone distribution}

The distribution of stratospheric ozone is determined by a balance of chemical ozone production and destruction combined with the effects of atmospheric motions that transport ozone and mix air with different ozone concentrations. In addition to chemical reactions that produce and destroy ozone naturally in the presence of oxygen (see "The Chapman Cycle"), ozone is destroyed in catalytic chemical processes that involve reactive gases containing hydrogen and nitrogen, as well as chlorine and bromine compounds (see "Catalytic ozone destruction").

\section{The Chapman Cycle}

Stratospheric ozone is formed in chemical reactions that require oxygen and sunlight [6]. First, an oxygen molecule $\left(\mathrm{O}_{2}\right)$ is split into two oxygen atoms $(\mathrm{O})$ by the absorption of solar UV radiation (Eq. 1). Each of the oxygen atoms then 
combines with an oxygen molecule in a 3-body-reaction to form an ozone molecule (Eq. 2):

$\mathrm{O}_{2}+h v \rightarrow \mathrm{O}+\mathrm{O} \quad \lambda \leq 242 \mathrm{~nm}$,

$\mathrm{O}_{2}+\mathrm{O}+\mathrm{M} \rightarrow \mathrm{O}_{3}+\mathrm{M}$.

Photochemical ozone production occurs in the stratosphere whenever solar UV radiation is available, and is, therefore, largest in the tropical stratosphere.

The production of stratospheric ozone is balanced by chemical destruction in which an ozone molecule is broken into an oxygen molecule and oxygen atom by absorption of solar UV radiation (Eq. 3). The oxygen atom then combines either with another oxygen molecule to form a new ozone molecule (Eq. 2), or combines with an ozone molecule to rebuild two oxygen molecules (Eq. 4):

$\mathrm{O}_{3}+h v \rightarrow \mathrm{O}_{2}+\mathrm{O} \quad \lambda \leq 1180 \mathrm{~nm}$,

$\mathrm{O}_{3}+\mathrm{O} \rightarrow 2 \mathrm{O}_{2}$.

The Chapman theory alone strongly overestimates the total ozone column in the tropics. However, it provides the basic chemical mechanism for the formation of the ozone layer on top of which other ozone destruction mechanisms act.

\section{Catalytic ozone destruction}

Away from the polar areas, stratospheric ozone production is largely balanced by catalytic destruction cycles of the form (Cycle 1) consisting of two or more separate reactions involving reactive gases:

Cycle 1: $\frac{\mathrm{X}+\mathrm{O}_{3} \rightarrow \mathrm{XO}+\mathrm{O}_{2}}{\mathrm{Net}: \mathrm{O}+\mathrm{O}_{3} \rightarrow 2 \mathrm{O}_{2}}$.

The net reaction is the destruction of one oxygen atom and one ozone molecule. The catalyst $\mathrm{X}$ is reformed at the end of each cycle and can destroy thousands of ozone molecules before it is removed from the stratosphere. These gases are the products of long-lived natural and anthropogenic source gases emitted at Earth's surface or by the oceans. They are transported into the stratosphere in the tropics, where they are photochemically converted into their reactive forms.

The first family of radicals considered in ozone chemistry was the $\mathrm{HO}_{\mathrm{x}}$ family consisting of atomic hydrogen $\mathrm{H}$, the hydroxyl radical $\mathrm{OH}$ and the hydroperoxyl radical $\mathrm{HO}_{2}[7$, 8]. $\mathrm{OH}$ radicals form in chemical reactions of excited oxygen atoms $\left(\mathrm{O}\left({ }^{1} \mathrm{D}\right)\right)$ with water vapour $\left(\mathrm{H}_{2} \mathrm{O}\right)$, methane $\left(\mathrm{CH}_{4}\right)$ or molecular hydrogen $\left(\mathrm{H}_{2}\right)$. Both water vapour and methane have tropospheric sources of natural and anthropogenic origin. Methane, for example, is emitted by natural wetlands but also by rice paddies and biomass burning.
Nitric oxide (NO), another radical causing the destruction of large amounts of ozone, forms in the stratosphere by photolytic reaction of nitrous oxide $\left(\mathrm{N}_{2} \mathrm{O}\right)$ with $\mathrm{O}\left({ }^{1} \mathrm{D}\right)$ [9] and, mainly at higher altitudes in the mesosphere, from the ionization of molecular nitrogen $\left(\mathrm{N}_{2}\right)$ by solar or galactic energetic particles. The source gas $\mathrm{N}_{2} \mathrm{O}$ is produced by bacterial processes in natural and cultivated soils. It has an estimated global lifetime of about 120 years, and is present throughout the troposphere with higher concentrations in the Northern Hemisphere. In the stratosphere, NO reduces ozone efficiently in rapid catalytic reactions during daytime, and to a lesser extent during night. However, a concurrent transformation of the nitrogen oxides ( $\mathrm{NO}$ and $\mathrm{NO}_{2}$, or $\mathrm{NO}_{\mathrm{x}}$ ) to less reactive substances, the so-called reservoir gases, acts as limiting factor for NO induced ozone depletion. Important reservoir gases are nitric acid $\left(\mathrm{HNO}_{3}\right)$, and chlorine and bromine nitrate $\left(\mathrm{ClONO}_{2}\right.$ and $\mathrm{BrONO}_{2}$ ).

Stratospheric ozone is further destroyed by reactions involving the reactive halogen gases chlorine $(\mathrm{Cl}, \mathrm{ClO})$ and bromine $(\mathrm{Br}, \mathrm{BrO})[10,11]$. The source gases of these halogen radicals are emitted at Earth's surface by human activities or natural processes. They accumulate and are globally distributed in the troposphere before they are transported into the stratosphere, where they are converted to reactive halogen gases. While these reside in the form of inactive reservoir gases $\left(\mathrm{ClONO}_{2}, \mathrm{BrONO}_{2}\right.$, and hydrogen chloride $\left.\mathrm{HCl}\right)$ in the lower stratosphere, they are converted to chlorine $(\mathrm{Cl})$ and chlorine monoxide $(\mathrm{ClO})$ radicals higher up, where they catalytically destroy ozone.

In polar regions during winter, the abundance of $\mathrm{ClO}$ is greatly enhanced due to reactions on the surfaces of Polar Stratospheric Clouds (PSCs) that form at the low temperatures found there, e.g. [12]. As at the same time atomic oxygen concentrations are reduced, Cycle 1 becomes less efficient and polar ozone loss is dominated by two other catalytic destruction cycles in which $\mathrm{ClO}$ reacts either with itself $(\mathrm{ClO}$ dimer cycle, Cycle 2 ) or with $\mathrm{BrO}$ (Cycle 3 ) to produce ozone destroying $\mathrm{Cl}$ and $\mathrm{Br}$ radicals. In Cycle 3, $\mathrm{ClO}$ and $\mathrm{BrO}$ can either react to the $\mathrm{Cl}$ and $\mathrm{Br}$ radicals directly or alternatively via the production of $\mathrm{BrCl}$ followed by photolysis (not shown):

$$
\begin{aligned}
\mathrm{ClO}+\mathrm{ClO}+\mathrm{M} \rightarrow(\mathrm{ClO})_{2}+\mathrm{M} \\
(\mathrm{ClO})_{2}+h v \rightarrow \mathrm{ClOO}+\mathrm{Cl} \\
\mathrm{ClOO}+\mathrm{M} \rightarrow \mathrm{Cl}+\mathrm{O}_{2}+\mathrm{M} \\
2\left(\mathrm{Cl}+\mathrm{O}_{3} \rightarrow \mathrm{ClO}+\mathrm{O}_{2}\right)
\end{aligned}
$$


Cycles 2 and 3 are only effective when sufficient $\mathrm{ClO}$ is produced, i.e. during wintertime. However, to maintain high $\mathrm{ClO}$ levels and to complete the cycles, sunlight is required. Cycles 2 and 3 account for most of the Arctic and Antarctic ozone loss by the end of the winter and early spring, when the rate of ozone destruction can reach 2-3\% per day.

Figure 3 shows that the halogen loss cycles are most effective in the upper stratosphere, where most halogen radicals are released from their reservoirs, and in the lower stratosphere, where the occurrence of PSCs leads to additional chemical ozone loss in polar winter and spring. Ozone loss in the middle stratosphere $(\sim 20-40 \mathrm{~km}$ altitude) is dominated by the $\mathrm{NO}_{\mathrm{x}}$ loss cycles explaining $70 \%$ of the total chemical ozone loss around $30 \mathrm{~km}$ height. The $\mathrm{HO}_{\mathrm{x}}$-cycles dominate in the lowermost stratosphere due to higher water vapour abundances and in the mesosphere, where a larger number of $\mathrm{H}$-radicals exists. More details about stratospheric ozone chemistry are found in [13].

\section{Ozone transport}

The net effect of chemical ozone production in the Chapman cycle and catalytic chemical destruction is the formation of the stratospheric ozone layer with a maximum ozone volume mixing ratio in the tropical middle stratosphere between about 30 and $35 \mathrm{~km}$ height. In the respective winter seasons, ozone is transported with the large-scale meridional residual circulation, the Brewer-Dobson circulation (BDC), from its tropical source region poleward and downward into the lower stratosphere, as indicated by the black arrows in Fig. 4 (see also [17]). This relocation is further supported by meridional mixing in the lower stratosphere. Thus, in

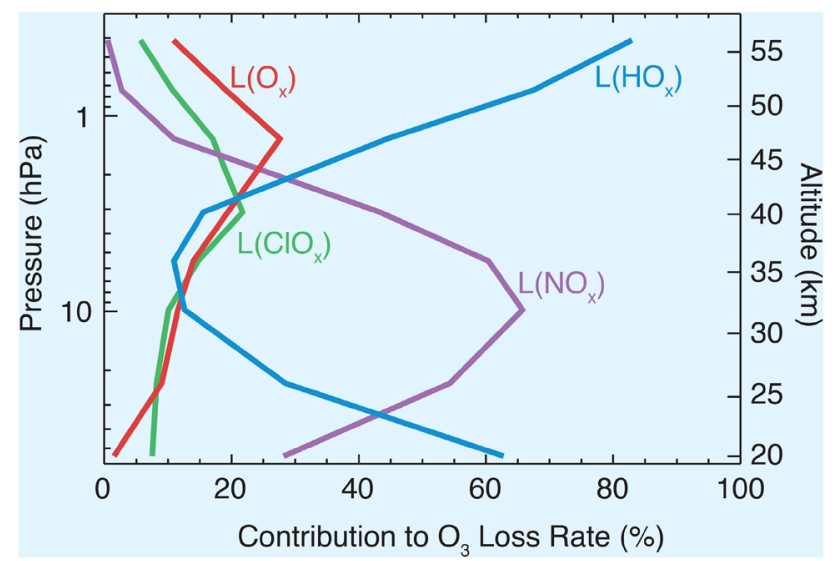

Fig. 3 Vertical distribution of the relative importance of the individual contributions to ozone loss by the $\mathrm{HO}_{\mathrm{x}}, \mathrm{ClO}_{\mathrm{x}}$ and $\mathrm{NO}_{\mathrm{x}}$ cycles as well as the Chapman loss cycle $\left(\mathrm{O}_{\mathrm{x}}\right)$. The calculations are based on HALOE (V19) satellite measurements and are for overhead sun $\left(23^{\circ} \mathrm{S}\right.$, January) and for total inorganic chlorine $\left(\mathrm{Cl}_{\mathrm{y}}\right)$ in the stratosphere corresponding to 1994 conditions. Updated and extended in altitude range from [14] and Chap. 6 of [15]. (From [16])

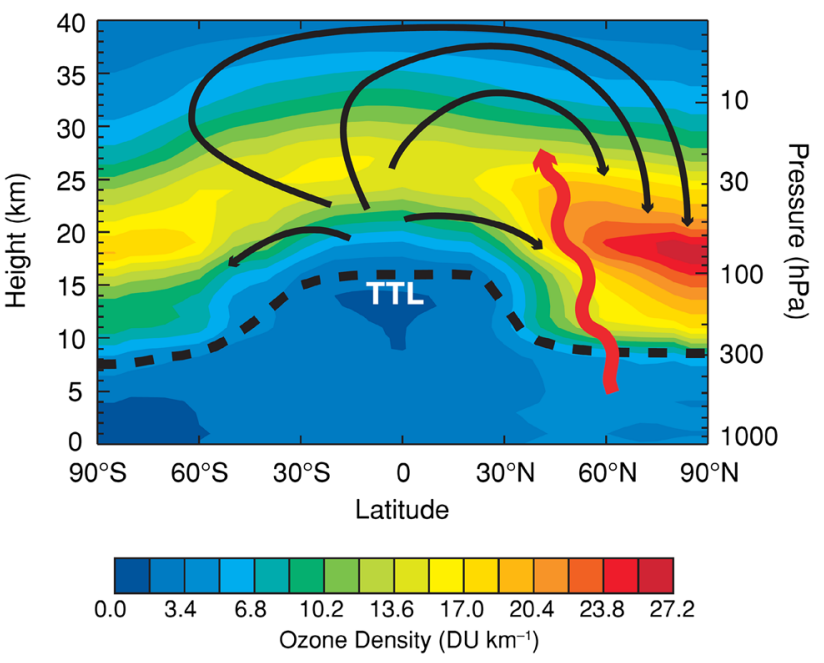

Fig. 4 Meridional cross-section of the atmosphere showing ozone density [colour contours; in Dobson units (DU) per km] during Northern Hemisphere (NH) winter (January-March), from the climatology of Fortuin and Kelder [18]. The dashed line denotes the tropopause, and TTL stands for tropical tropopause layer. The black arrows indicate the Brewer-Dobson circulation during $\mathrm{NH}$ winter, and the red arrow represents planetary waves that propagate from the troposphere into the winter stratosphere. (From [16])

terms of ozone mass, the ozone layer varies between about $10-15 \mathrm{~km}$ altitude at high latitudes and $20-25 \mathrm{~km}$ in the tropics (Fig. 4). Note that the height range with maximum ozone mass is located about $10 \mathrm{~km}$ lower in the stratosphere than the main ozone production region. The vertically integrated total ozone column reaches highest values at middle to polar latitudes. Figure 4 shows the resulting climatological annual mean distribution of ozone derived from observations [16].

\section{Anthropogenic ozone depletion}

\section{Threat by human activities}

In the early 1970s, Johnston was among the first to point to a potential threat to the ozone layer by increasing nitrogen source gases to be emitted by a projected US fleet of supersonic aircrafts [19]. A few years later, Molina and Rowland suggested that the increasing consumption of industrially manufactured chlorofluorocarbons, in particular CFC-11 $\left(\mathrm{CCl}_{3} \mathrm{~F}\right)$ and $\mathrm{CFC}-12\left(\mathrm{CCl}_{2} \mathrm{~F}_{2}\right)$, provides the major source of stratospheric chlorine, and therefore, might lead to a reduction of the ozone layer [20]. In the 1980s and 1990s, when stratospheric reactive halogens (also known as ODSs) reached their highest concentrations, satellites recorded a substantial decline of northern mid-latitude ozone in the middle and upper stratosphere by about $-7 \%$ per decade ([21], Fig. 5, left). Climate models, considering the 


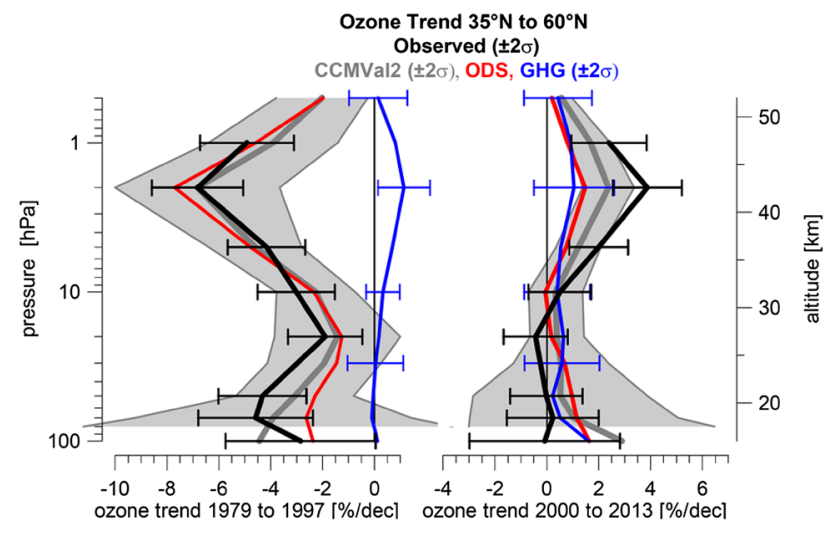

Fig. 5 Observed and modeled ozone trend profiles [\%/decade] averaged over the $35^{\circ} \mathrm{N}-60^{\circ} \mathrm{N}$ latitude band for the periods $1979-1997$ (left panel) and 2000-2013 (right panel). Black line with bars: Average of available ground-based and satellite observations, with \pm 2 standard deviation uncertainty range. Gray line with shading: Corresponding mean trends from CCMVal-2 REF-B2 chemistry-climate model (CCM) simulations using ODS and GHG forcing (but only for the subset of seven models that did simulations with fixed GHGs), with uncertainty range given by \pm 2 standard deviations of individual model trends (not including volcanos and solar cycle). Red line: Trend attributed to ODS changes alone from CCM simulations with fixed 1960 GHG concentrations (seven models). Blue line: Trend attributed to increasing GHG abundances alone from CCM simulations with fixed 1960 ODS concentrations (nine models). Observed trends are from multi-linear regression accounting for QBO, solar cycle, volcanic aerosol and ENSO. (From [21])

chemical effects of ODSs on ozone, were able to reproduce the observed ozone decline in the upper stratosphere, thus confirming the causal relationship between ODSs and the observed ozone decline (e.g., [21, 22], Fig. 5, left). Global annual mean total ozone in the mid-1990s was about 5\% below the 1964-1980 average with the ozone depletion being enhanced by the effects of the Pinatubo volcanic eruption in 1991 (Fig. 6).

\section{The Antarctic ozone hole}

The risks of halogen and nitrogen source gases for the ozone layer were recognized early by the scientific community. However, the severe ozone decline over Antarctica, measured since the early 1980s by ground-based measurements at the Antarctic research stations Syowa [23] and Halley Bay [24] came completely unexpected. This continent-wide ozone depletion, later named Antarctic ozone hole, started to develop in the mid-1970s, and is, since then, a regular annual phenomenon in late winter and early spring at southern polar latitudes (Fig. 7). The ozone loss over Antarctica is largest in the $10-20 \mathrm{~km}$ height range where nearly complete ozone depletion is observed on individual days. It occurs too low in the stratosphere to be explained by the catalytic ozone depletion cycles that dominate higher up. This ozone hole

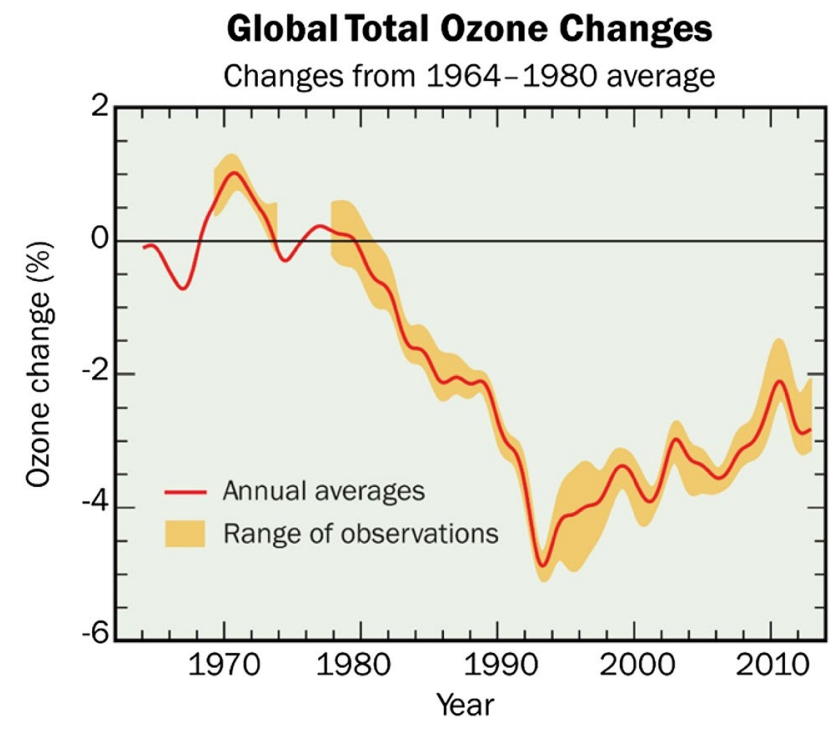

Fig. 6 Global total ozone changes. Satellite observations show depletion of global total ozone beginning in the 1980s. Annual averages of global ozone are compared with the average from the period 19641980 before the ozone hole appeared. Seasonal and solar effects have been removed from the observational dataset. On average, global ozone decreased each year between 1980 and 1990. The depletion worsened for a few years after 1991 due to the effect of volcanic aerosol from the Mt. Pinatubo eruption. (From [21])

appears because of a specific combination of meteorological and chemical conditions over Antarctica which increases the effectiveness of ozone destruction by reactive halogens. The severe ozone depletion in the ozone hole requires low temperatures to be present over an extended period in the lower stratosphere to enable the formation of solid and liquid PSCs. Only over Antarctica, where the lower stratosphere is persistently colder in winter than in the Arctic, sufficiently large areas with nitric acid $\left(\mathrm{HNO}_{3}\right)$ or ice PSCs can build to provide the conditions for the formation of an ozone hole $[25,26]$. By heterogeneous reactions of the halogen reservoir gases on the PSC surfaces, nearly all available chlorine and bromine are converted to their most reactive forms $\mathrm{ClO}$ and $\mathrm{BrO}$ (e.g., [12, 27-29]; see also "Catalytic ozone destruction"), which in sunlight eventually destroy ozone.

\section{Turning point: The Montreal Protocol}

Given the growing evidence of the harmful effects by anthropogenic halogens on the ozone layer and rising concerns on the associated risks for life and human health by enhanced surface-UV, WMO started with the 1977 World Plan of Action on the Ozone Layer a series of international scientific assessments. Following the Vienna Convention for the Protection of the Ozone Layer in 1985, the Montreal Protocol on Substances that Deplete the Ozone Layer was signed in 1987. The Montreal Protocol, which 


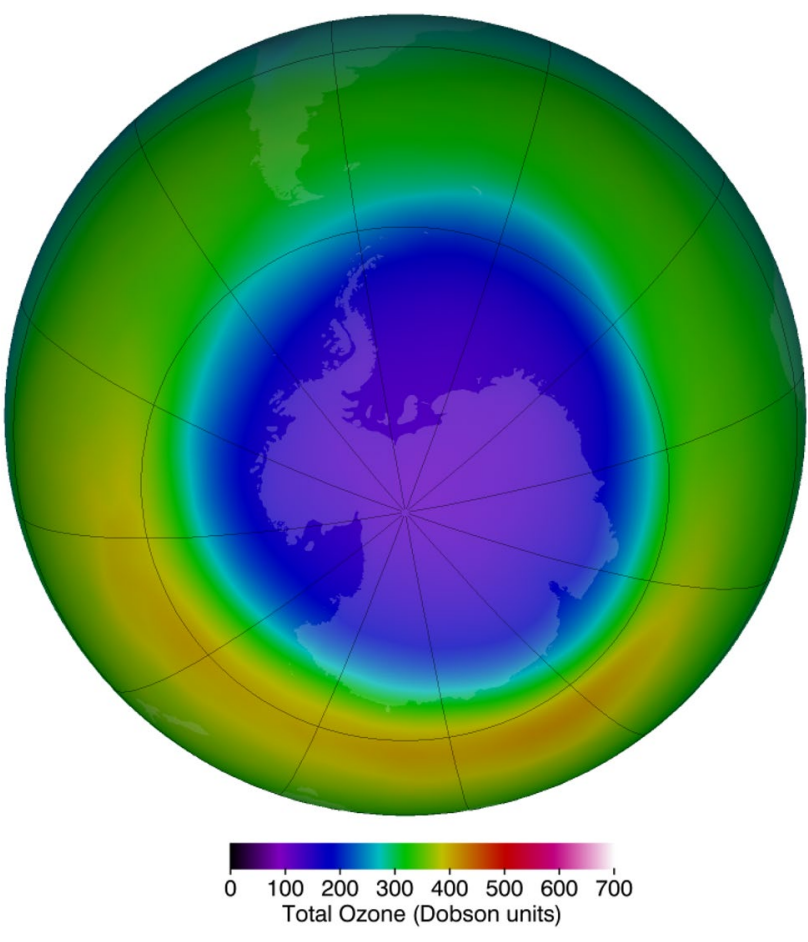

Fig. 7 Monthly mean total column ozone for high southern latitudes in October 2018 as measured by the Ozone Mapping Profiler Suite (OMPS) instrument on board the Suomi National Polar-orbiting Partnership (NPP) satellite. The dark blue and purple regions over the Antarctic continent show the severe ozone depletion or "ozone hole" found during every spring. Minimum values of total ozone inside the ozone hole are close to 100 Dobson units (DU) compared with normal Antarctic springtime values of about 350 DU. The ozone hole area is usually defined as the geographical area within the 220-DU contour on total ozone maps. (From https://ozonewatch.gsfc.nasa. gov/)

is now ratified by all 196 United Nations members, and subsequent Amendments and adjustments, successfully established legally binding controls for developed and developing countries on the production and consumption of halogen source gases that cause ozone depletion. As a result, the overall abundance of ODSs in the atmosphere has been decreasing since the late 1990s (Fig. 8), and upper stratospheric ozone increases again significantly since the turn of the century ([21], Fig. 5, right). Global total ozone values are still lower than in the pre-1980 era but they have ceased to decline (Fig. 6) [21]. However, due to the long residence time of the ODSs in the stratosphere, large effects of natural variability and the confounding impacts of climate change (see "The role of climate change") it is not yet possible to detect a statistically significant increase of global total column ozone [30]. Through the implementation of the Montreal Protocol, much larger ozone depletion than currently observed has been avoided in the polar regions of both hemispheres [31].
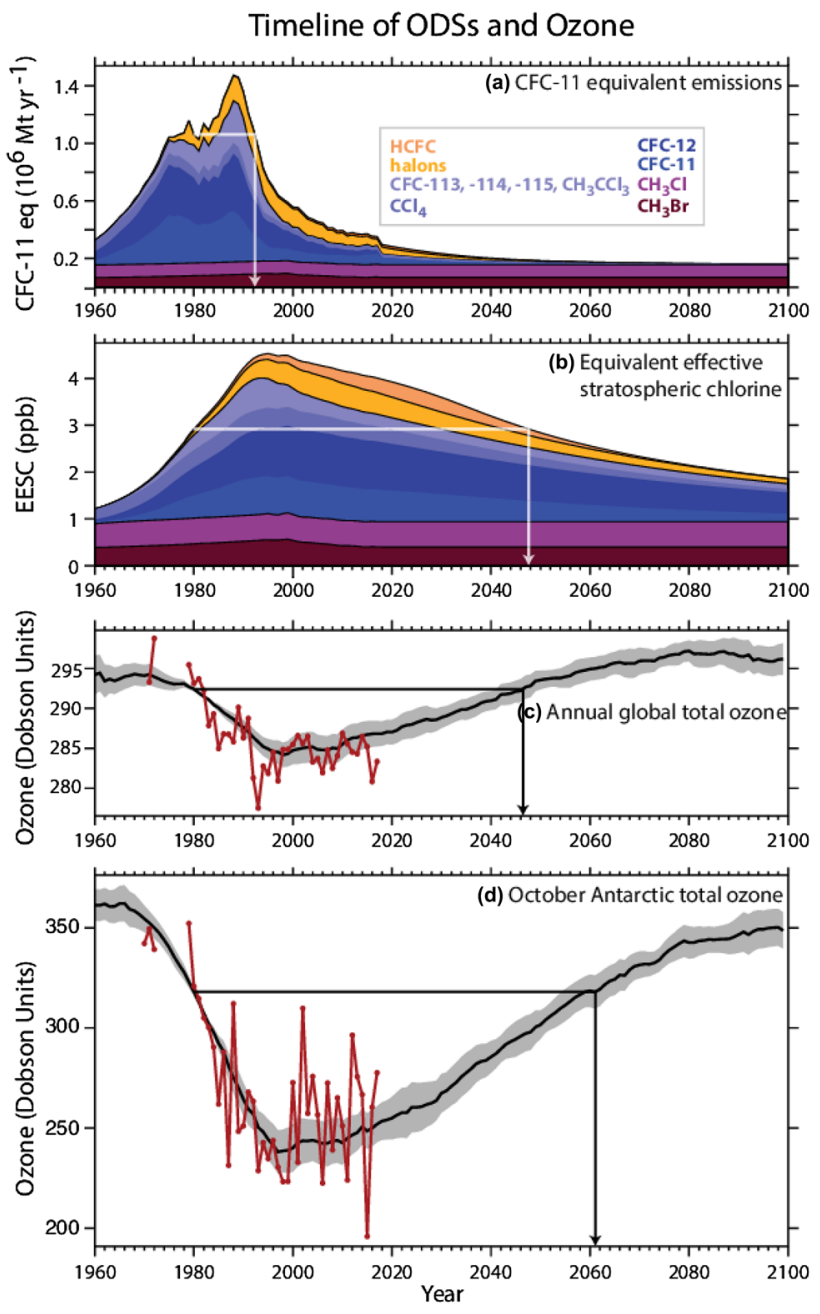

Fig. 8 Timeline of: a CFC-11-equivalent emissions, b EESC, c global total ozone, and d October Antarctic total ozone. Annual CFC-11-equivalent emissions are computed for the ODSs shown in the legend by multiplying mass emissions of a substance by its ozone depletion potential (ODP) (a). Historical emissions are derived from the measured atmospheric concentrations of individual ODSs from measurement networks. The future projections of emissions assume full compliance with the Montreal Protocol and use standard methodologies based on reported production, inventory-estimates of the banks and release rates. The annual abundances of equivalent effective stratospheric chlorine (EESC), shown for the Antarctic stratosphere, are based on surface abundances (measured or derived from projected emissions and lifetimes) of the chlorine- and bromine-containing substances (b). The bromine abundances are weighted by a factor of 60 to account for the greater efficiency of bromine in ozone destruction reactions in the atmosphere. Global total column ozone represents an average over $60^{\circ} \mathrm{N}-60^{\circ} \mathrm{S}$ latitudes (c) and Antarctic total column ozone represents an average over $60^{\circ} \mathrm{S}-80^{\circ} \mathrm{S}$ latitudes (d). c, d include a comparison of chemistry-climate model results (black lines with gray shadings indicating uncertainty ranges) and available observations (data points). The model projections into the future assume compliance with the Montreal Protocol and an increase in GHGs following the RCP 6.0 scenario. The lines with arrows mark when CFC-11-equivalent emissions (a), EESC (b) and ozone abundances (c, d) return to their 1980 values. (From [30]) 


\section{Future evolution of stratospheric ozone}

\section{Recovery of stratospheric ozone}

Climate models with interactive ozone chemistry assuming compliance with the provisions of the Montreal Protocol project a return of global annual mean total column ozone (TCO) to values of 1980 around mid-century, while over Antarctica TCO will reach the 1980 benchmark about 10 years later [32] (Fig. 8). On global average, TCO will return to its 1980 benchmark at about the same time as Equivalent Effective Stratospheric Chlorine (EESC), which is a metric for the total halogen content of the stratosphere based on surface abundances (measured or derived from projected emissions and lifetimes) of the chlorine- and brominecontaining substances (Fig. 8). However, the return dates of TCO to its 1980 baseline values differ regionally (Table 1), as effects other than ODSs have regionally varying impacts on ozone recovery (see "The role of climate change"). The broad range of projected return dates of TCO for a specific region, indicated by the values in brackets in Table 1, results from the complexity and diversity of the applied chemistryclimate models.

\section{The role of climate change}

With ODS concentrations declining in the coming decades, ozone will be affected more strongly by climate change. Models project that rising greenhouse gas (GHG) concentrations will cool the middle and upper stratosphere and thereby reduce chemical gas-phase ozone depletion, leading to a future ozone increase in the upper stratosphere. Enhanced GHGs are also projected to strengthen the stratospheric BDC, leading to a growing poleward and downward

Table 1 Total column ozone return dates to 1980 baseline from multi-model mean of Chemistry Climate Model Initiative (CCMI) model simulations using future projections for GHGs (RCP 6.0 scenario) and ODS [33]

\begin{tabular}{ll}
\hline Region & $\begin{array}{l}\text { Return year to } 1980 \\
\text { baseline values }\end{array}$ \\
\hline Global & $2049(2043-2055)$ \\
SH pole (October) & $2060(2055-2066)$ \\
SH mid-latitudes & $2045(2039-2050)$ \\
Tropics & $2058(2038-2100)$ \\
NH mid-latitudes & $2032(2020-2044)$ \\
NH pole (March) & $2034(2025-2043)$ \\
\hline
\end{tabular}

Values in brackets indicate range of return dates based on $1 \sigma$ standard deviation. The ' 2100 ' in italics indicates that the estimated ozone uncertainty range has not reached the 1980 values within the time range of the simulations. (From [32]) transport of ozone (e.g., [34]). The implications of rising GHG concentrations are, therefore, particularly pronounced in Arctic spring and in the tropics. While the evolution of total column ozone in Antarctica in spring is largely determined by the past increase and future decline of ODSs (red curve in Fig. 9, top), rising GHG concentrations further enhance the ODS induced ozone recovery in future Arctic spring and lead to higher total column ozone values by the end of the twenty-first century than before the era of manmade ozone depletion (red curve in Fig. 9, bottom). While the ODSs have been the primary driver of observed Arctic TCO trends in the past, changes in GHGs will exert the dominant control over Arctic ozone distributions by the late twenty-first century. Different possible future evolutions of GHGs, the so-called Representative Concentration Pathways (RCPs), have been constructed for climate model projections [35]. Assuming the medium RCP 6.0 GHG scenario, they accelerate the return of Arctic total column ozone to its 1960
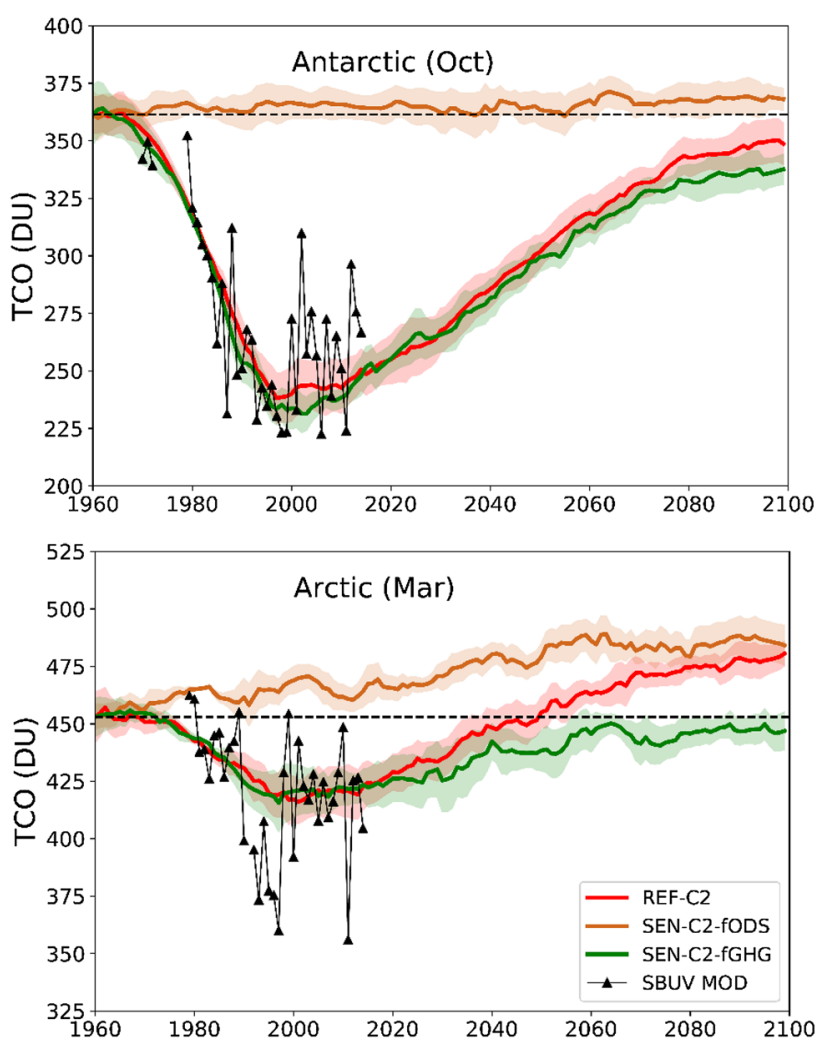

Fig. 9 Temporal evolution of multi-model means of total column ozone (TCO, Dobson Units) for Antarctic spring (October, top) and Arctic spring (March, bottom) derived from CCMI scenario calculations for fixed ODSs of the year 1960 (brown), and fixed GHGs of the year 1960 (green), in comparison with a reference simulation including transient ODSs and GHGs of the period 1960-2100 (red). SBUV MOD observations are included for the period 1979-2017 (black). The solid lines show the multi-model mean; shaded areas denote \pm 1 standard deviation. The dashed lines show the 1960 multi-model mean ozone. (Adapted from [32]) 
baseline value and lead to a further increase by about $20 \mathrm{DU}$ above 1960 levels until the end of the century.

In the tropics, the future evolution of total column ozone will be the result of opposing effects of growing GHG abundances in different atmospheric layers ([36], Fig. 10). In the upper stratosphere-at pressures lower than $10 \mathrm{hPa}$ - ozone will increase as a combined effect of declining ODS and rising GHG concentrations. The GHG induced cooling of the upper stratosphere and the associated ozone increase are strongest for the extreme RCP 8.5 GHG scenario. In contrast, in the lower stratosphere-at pressures between 100 and $10 \mathrm{hPa}$ - tropical ozone will decrease due to a projected increase in tropical upwelling driven by rising GHG concentrations. This ozone loss is strongest for the extreme RCP 8.5 scenario. Given the larger ozone abundance in the lower stratosphere, the net effect will be a future decline of stratospheric tropical ozone column which is strongest for the extreme RCP 8.5 GHG scenario. This stratospheric ozone decline is, however, counteracted by a large increase in tropospheric ozone (at pressures between 1000 and $100 \mathrm{hPa}$ ), specific to the RCP $8.5 \mathrm{GHG}$ scenario in which a strong future increase in methane is assumed. As a result, total column ozone in the tropics is projected to be lower by the end of the twenty-first century than in the 1960s. However, the ozone deficit will be strongest for the medium RCP 6.0 scenario, as the strong ozone loss in the extreme RCP 8.5 scenario will be counteracted by tropospheric ozone production.

\section{Environmental impacts}

\section{Changes in harmful UV-B irradiance}

Figure 11 (left) summarizes the annual mean global changes in TCO which occurred in the period of rising ODSs (1960-1990, top row) and which are projected in CCM simulations by the end of the twenty-first century (1960-2090) for the moderate, medium and extreme RCP GHG scenarios [36]. While TCO decreased during the ODS era, particularly in northern mid-latitudes, the southern hemisphere and over Antarctica, it will generally recover by the end of the twenty-first century in the mid-high latitudes of both hemispheres. This increase in TCO will be strongly steered by the amount of emitted GHGs: In the extreme RCP 8.5 GHG scenario total column ozone increases will be strongest leading to a so-called super-recovery in the northern hemisphere mid-high latitudes reaching higher levels than in 1960. In contrast, tropical total column ozone will remain below its 1960 levels, with strongest future ozone loss in the medium RCP scenario, as discussed in "The role of climate change". This continued ozone depletion will have consequences for life in the tropics. Figure 11 (right) shows the changes in surface UV-B irradiance integrated over those wavelengths

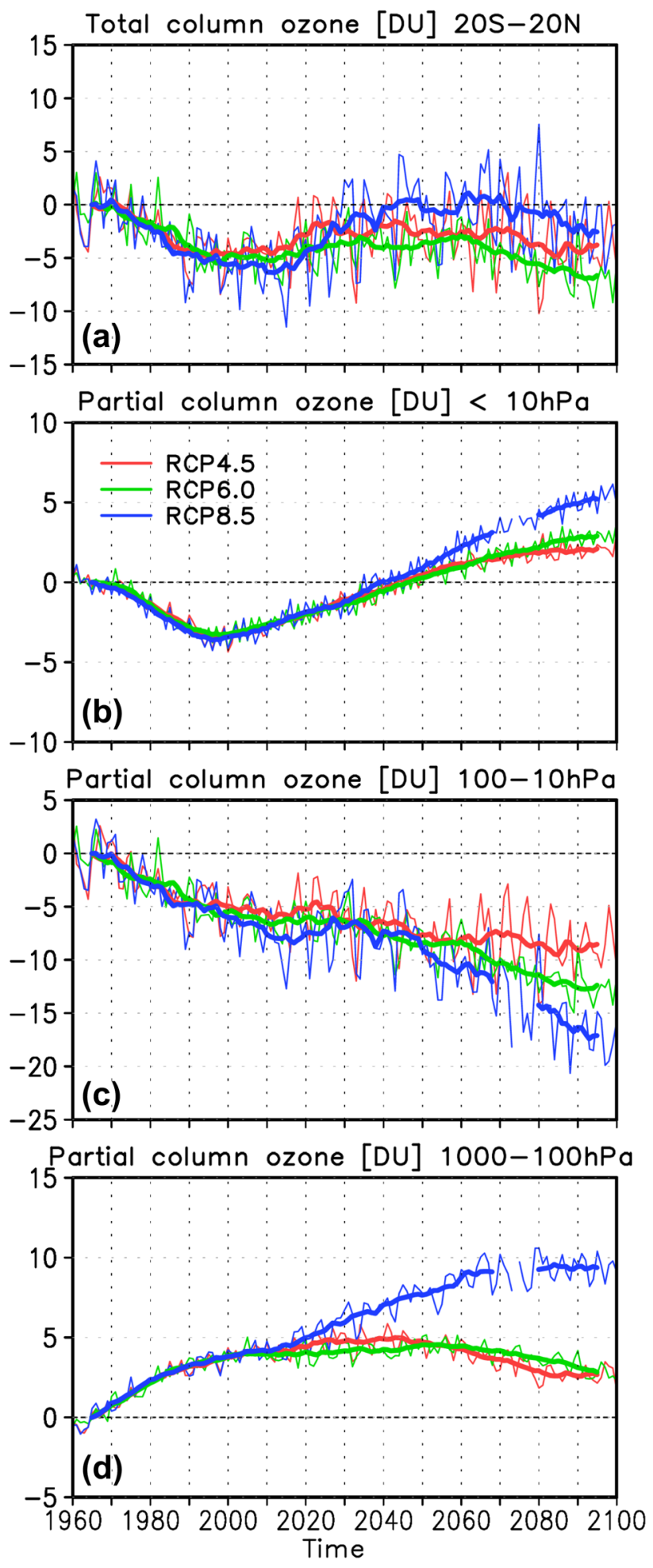

Fig. 10 a Evolution of annual tropical mean $\left(20^{\circ} \mathrm{S}-20^{\circ} \mathrm{N}\right)$ total column ozone anomaly from the 1960-1970 mean in chemistry-climate model simulations using the RCP 4.5 (red), RCP 6.0 (green), and RCP 8.5 (blue) GHG scenarios, b-d same as a but for the partial column ozone (PCO) for the $\mathbf{b}$ upper stratosphere (pressure $\leq 10 \mathrm{hPa}$ ), c middle stratosphere $(100 \mathrm{hPa} \geq$ pressure $>10 \mathrm{hPa})$, and d troposphere $(1000 \mathrm{hPa} \geq$ pressure $>100 \mathrm{hPa})$. Thick solid lines indicate the smoothed time series. (From [36]) 

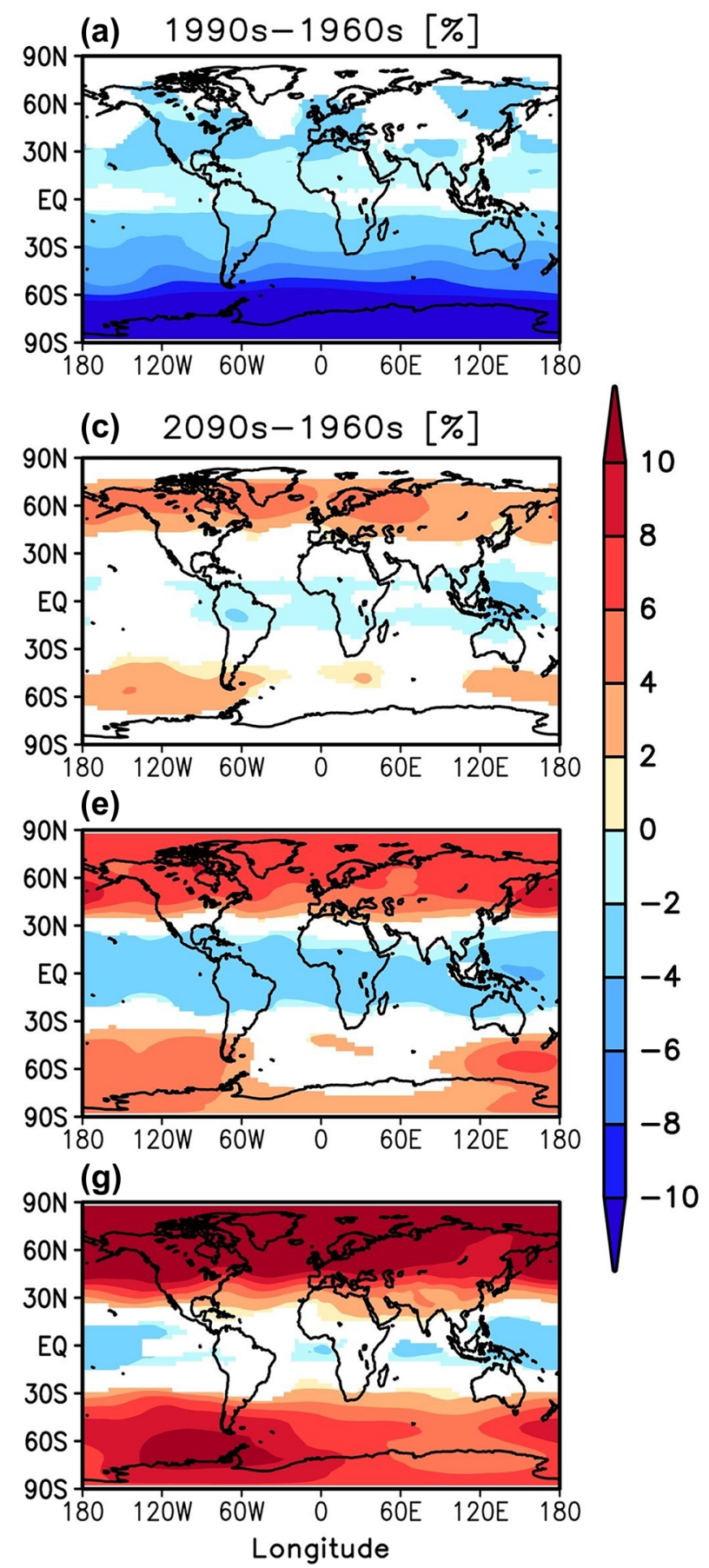

Fig. 11 Differences in annual mean total column ozone (in \%, left column) and UVB-DNA (integral of UV-B irradiance weighted with the DNA-damage action spectrum) at the surface (in \%, right column) between the 1960s and 1990s (top row) and between the 1960s and

that are able to damage human DNA (deoxyribonucleic acid) $(\lambda=280-315 \mathrm{~nm})$, calculated for the TCO changes in the three RCP GHG scenarios, shown in Fig. 11 (left). The integral of the UV-B radiation has been weighted with the DNA-damage action spectrum (UVB-DNA; based on [37,
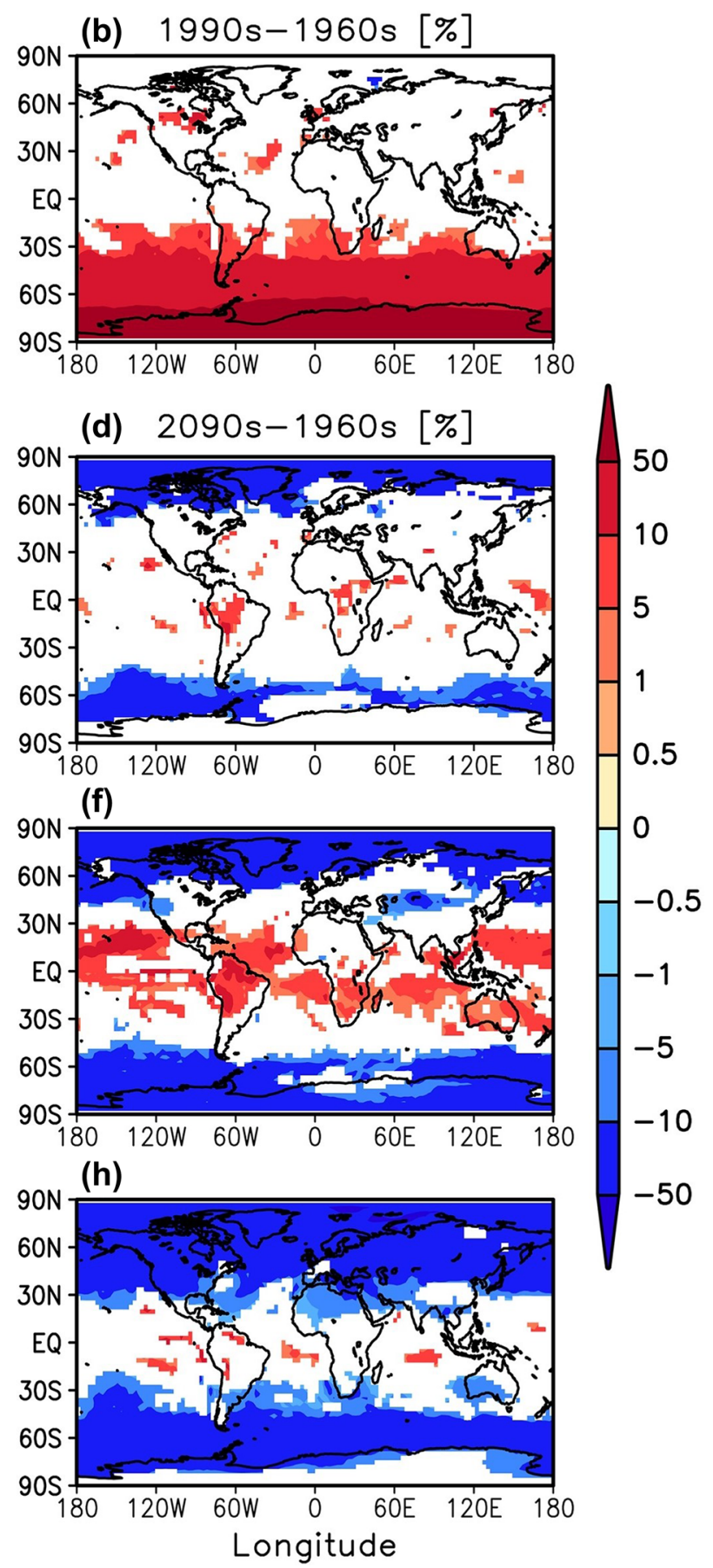

2090s for a moderate (2nd row), medium (3rd row) and strong (4th row) greenhouse gas scenario, derived from chemistry-climate model simulations. (Adapted from [36])

38]) and consistently accounts for changes in ozone concentration and cloudiness.

In the past, the tropical latitudes, which are on average exposed to high UVB-DNA, were not significantly affected by ODS-induced ozone depletion. However, a significant 
Table 2 Change in crosstropopause ozone mass flux between 2000 and 2100 . The numbers indicate changes relative to the year 2000 . All changes are significant at the 95\% confidence level (From [38])

increase of UVB-DNA by $10-30 \%$ in the southern subtropics and by more than $100 \%$ at high latitudes occurred due to the development of the Antarctic spring ozone loss. Consistent with the projected future changes in TCO (Fig. 11, left), less UV-B irradiance will reach the surface in both the northern and southern high latitudes by the end of the century compared to the 1960s, whereas in the tropics all scenarios show the tendency to an UVB-DNA increase (Fig. 11, right). The largest significant increase of $15 \%$ is expected for the medium RCP6.0 GHG scenario, with South America, South Africa, and Australia being affected most. In the tropical mean, the UVB-DNA changes from the 1960s to the 2090s vary between +1 to $+5 \%$ between the RCP GHG scenarios. Similar geographical patterns in erythemally weighted UV-B radiation were derived from A1B-projections of CCMVal-2 models [39].

\section{Stratospheric ozone in the troposphere}

Ozone in the troposphere has two sources: photochemical production involving ozone precursor species such as carbon monoxide $(\mathrm{CO})$, nitrogen oxides $\left(\mathrm{NO}_{\mathrm{x}}\right)$, and hydrocarbons (e.g., methane, $\mathrm{CH}_{4}$ ), and the transport of ozone from the stratosphere into the troposphere [40]. In the lowermost stratosphere, where the chemical lifetime of ozone is larger than the transport timescale, ozone can be transported into the troposphere via tropopause folds near the polar and the subtropical jets and in cutoff lows [41, 42]. Vertical mass exchange is also possible by large-scale downwelling in the stratospheric BDC, which is driven by diabatic cooling [42]. Given the projected future recovery of the stratospheric ozone layer, the ozone mass flux from the stratosphere into the troposphere is expected to increase. A CCM projects that the global ozone mass flux from the stratosphere into the troposphere of $712 \pm 26 \mathrm{Tg}$ in the year 2000 will be $53 \%$ higher in 2100 (Table 2, [43]). This increase is dominated by effects of rising GHGs (46\%), with stratospheric ozone recovery due to declining ODSs contributing only $7 \%$. The relative contribution of rising $\mathrm{GHG}$ abundances to this global ozone increase will be larger in the $\mathrm{NH}(51 \%)$ than in the $\mathrm{SH}(40 \%)$, while the contribution of declining ODS concentrations will be stronger in the $\mathrm{SH}(9 \%)$ than in the $\mathrm{NH}(4 \%)$.
Figure 12 shows how the distribution of stratospheric ozone will change in the troposphere in the future [43]. Stratospheric ozone is projected to increase throughout the extratropical troposphere, particularly in the subtropical upper and middle troposphere. In these regions ozone is efficiently transported into the troposphere through tropopause folds. This process will be enhanced in the future by the rising GHG concentrations (Fig. 12b). Declining ODS concentrations will, in contrast, lead to higher amounts of stratospheric ozone in the upper troposphere at mid-high latitudes (Fig. 12c), indicating large-scale downwelling of increased stratospheric ozone concentrations and diffusion into the troposphere. In total, global tropospheric ozone will increase by $31 \%$ from 2000 to the end of the twentyfirst century, primarily in response to rising GHG abundances. The amount of stratospheric ozone in the troposphere will increase by $42 \%$ over the same time period. Also, the relative importance of ozone from the stratosphere will increase, reaching $49 \%$ in the $\mathrm{NH}$ and $55 \%$ in the SH around the year 2100. Thus, in the RCP6.0 GHG scenario half of the ozone in the troposphere will originate from the stratosphere by the end of the century [43].

\section{Conclusions}

The Montreal Protocol and its subsequent Amendments and adjustments have successfully limited the abundance of ODSs in the atmosphere. Consistent with this, upper stratospheric ozone has increased since 2000 by $1-3 \%$ per decade outside the polar regions. However, due to the long residence time of the ODSs in the stratosphere, large effects of natural variability and the confounding impacts of climate change it is not yet possible to detect a statistically significant increase of global total column ozone [30]. Models project a return of global ozone to 1980 values by the middle of the century, while the Antarctic ozone hole is projected to close around 2060. By the end of the century the effects of growing GHG concentrations will have a dominant effect on stratospheric ozone in the Arctic and the tropics. 


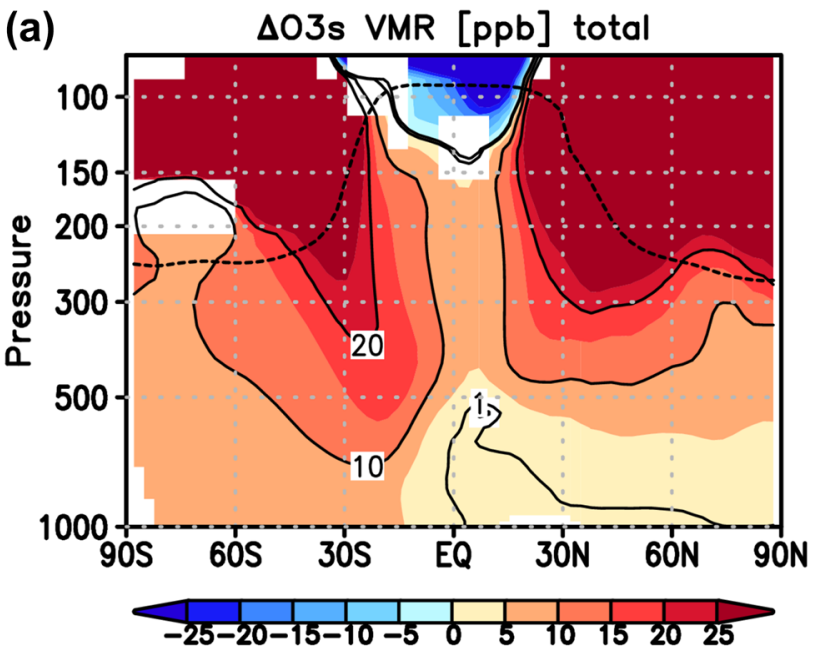

(b)

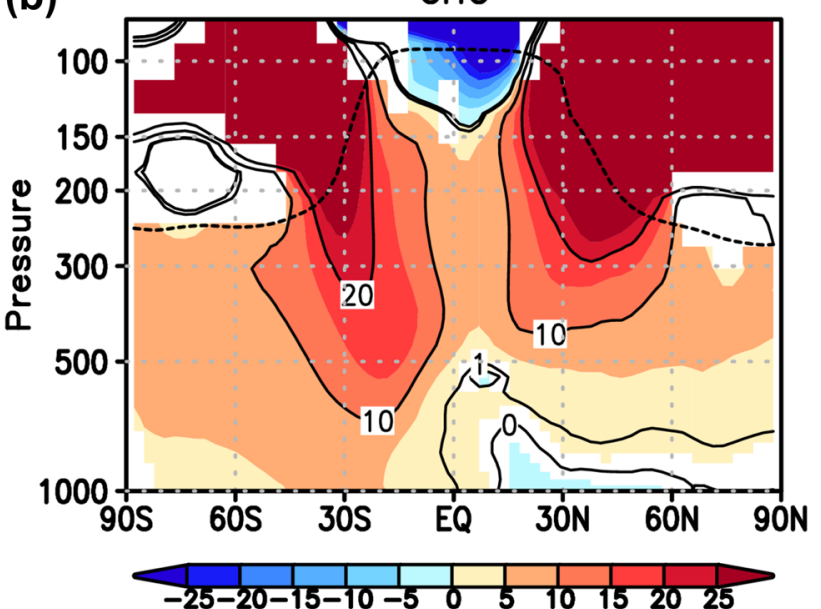

(c)

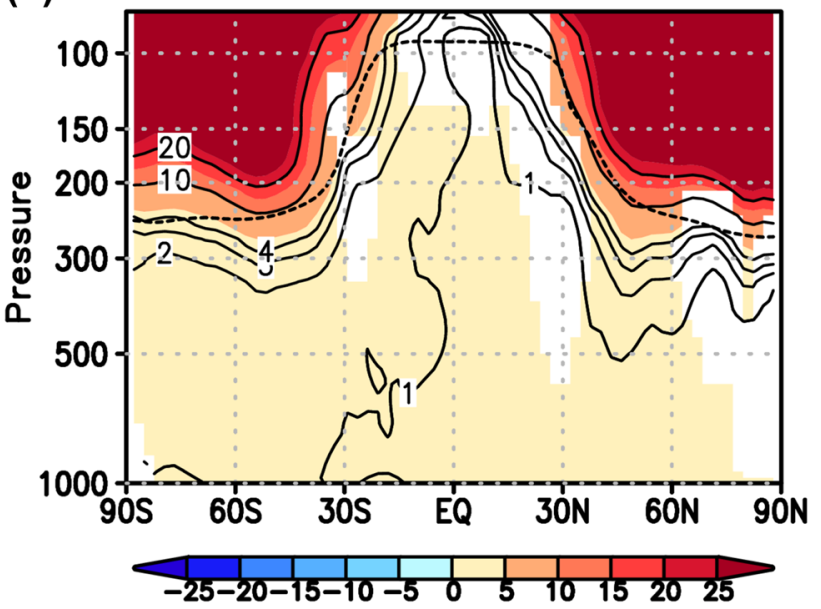

Fig. 12 Changes in the volume mixing ratio [ppbv] of stratospheric ozone in the troposphere in June a due to ODS and GHG changes between 2000 and 2100, b due to increasing GHG concentrations between 2000 and 2100, and $\mathbf{c}$ due to declining ODS levels between 2000 and 2100. Significant changes at the $95 \%$ confidence level are coloured. The black dotted line represents the mean tropopause position in the year 2000. For the small ODS-induced changes in $\mathbf{c}$ additional contour lines (2, 3, and 4 ppbv) are shown (From [43])
Acknowledgements Parts of this work have been supported by the Deutsche Forschungsgemeinschaft (DFG) within the DFG Research Unit FOR 1095 "Stratospheric Change and its Role for Climate Prediction" (SHARP).

Open Access This article is distributed under the terms of the Creative Commons Attribution 4.0 International License (http://creativeco mmons.org/licenses/by/4.0/), which permits unrestricted use, distribution, and reproduction in any medium, provided you give appropriate credit to the original author(s) and the source, provide a link to the Creative Commons license, and indicate if changes were made.

\section{References}

1. World Meteorological Organization (WMO) (2007) Scientific assessment of ozone depletion: 2006, global ozone research and monitoring project-report no. 50, Geneva, Switzerland, p 572

2. Hartley WN (1880) Chem News Nov 26:268

3. Fabry C, Buisson H (1913) J Physique 3(5):196-2016

4. Dobson GMB (1931) Proc Phys Soc Lond 4:324

5. Götz FWP, Meetham AR, Dobson GMB (1934) Proc Phys Soc Lond A145:416

6. Chapman S (1930) Mem R Soc 3:103

7. Bates D, Nicolet M (1950) J Geophys Res 55:301-327

8. Nicolet M (1970) Annl Geophys 26:531

9. Crutzen PJ (1970) Quart J R Met Soc 96:320

10. Stolarski RS, Cicerone RJ (1974) Can J Chem 52:1610

11. Wofsy SC, McElroy MM, Tung YL (1975) Geophys Res Lett $2: 215$

12. Solomon S, Garcia RR, Rowland FS, Wuebbles DJ (1986) Nature 321:755

13. Brasseur GP, Solomon S (2005) Aeronomy of the middle atmosphere. Springer, The Netherlands

14. Grooß JU, Müller R, Becker G, McKenna DS, Crutzen PJ (1999) J Atmos Chem 34(2):171-183

15. World Meteorological Organization (WMO) (1999) Scientific assessment of ozone depletion: 1998. Global ozone research and monitoring project-report no. 44, Geneva, Switzerland

16. IPCC/TEAP, Metz B, Kuijpers L, Solomon S, Andersen SO, Davidson O, Pons J, de Jager D, Kestin T, Manning M, Meyer L (eds) (2005) Safeguarding the ozone layer and the global climate system: issues related to hydrofluorocarbons and perfluorocarbons. Cambridge University Press, Cambridge, pp 478

17. Butchart N (2014) Rev Geophys 52:157-184. https://doi. org/10.1002/2013RG000448

18. Fortuin JPF, Kelder H (1998) J Geophys Res 103:31709-731734

19. Johnston HS (1971) Science 173:517

20. Molina MJ, Rowland FS (1974) Nature 249:810

21. World Meteorological Organization (WMO) (2014) Scientific assessment of ozone depletion: 2014, global ozone research and monitoring project-report no. 55, Geneva, Switzerland, p 416

22. Oman LD, Waugh DW, Kawa SR, Stolarski RS, Douglass AR, Newman PA (2010) J Geophys Res 115:D05303. https://doi. org/10.1029/2009JD012397

23. Chubachi S (1984) Mem Natl Inst Polar Res 34(special issue): $13-19$

24. Farman JC, Gardiner BG, Shanklin JD (1985) Nature 315:207

25. Crutzen PJ, Arnold F (1986) Nature 324:651

26. Toon OB, Hamill P, Turco RP, Pinto J (1986) Geophys Res Lett 13:1284

27. McElroy MB, Salawitch RJ, Wofsy SC, Logan JA (1986) Nature 321:759

28. Molina LT, Molina MJ (1987) J Phys Chem 91:433 
29. Anderson JG, Brune WH, Proffitt MH (1989) J Geophys Res 94:11,479

30. World Meteorological Organization (WMO) (2018) Executive summary: scientific assessment of ozone depletion: 2018, World Meteorological Organization, global ozone research and monitoring project-report no. 58, Geneva, Switzerland, p 67

31. Chipperfield MP, Dhomse SS, Feng W, McKenzie RL, Velders GJM, Pyle JA (2015) Nat Commun 6:7233. https://doi. org/10.1038/ncomms 8233

32. Dhomse $\mathrm{S}$ et al (2018) Atmos Chem Phys 18:8409-8438. https ://doi.org/10.5194/acp-18-8409-2018

33. World Meteorological Organization (WMO) (2011) Scientific assessment of ozone depletion: 2010, global ozone research and monitoring project-report no. 52, Geneva, Switzerland, p 516

34. Oberländer S, Langematz U, Meul S (2013) J Geophys Res Atmos 118:10296-10312. https://doi.org/10.1002/jgrd.50775

35. Meinshausen M et al (2011) Clim Change 109:213-241. https:// doi.org/10.1007/s10584-011-0156-Z

36. Meul S, Dameris M, Langematz U, Abalichin J, Kerschbaumer A, Kubin A, Oberländer-Hayn S (2016) Geophys Res Lett 43:2919_ 2927. https://doi.org/10.1002/2016GL067997
37. Setlow RB (1974) Proc Natl Acad Sci USA 71(9):3363-3366

38. National Research Council (1982) Causes and effects of stratospheric ozone reduction: an update. Natl. Acad. Press, Washington, $\mathrm{p} 339$

39. Bais AF et al (2011) Atmos Chem Phys 11(15):7533-7545

40. IPCC (2001) Climate change 2001: the scientific basis, contribution of working group 1 to the third assessment report, Cambridge, United Kingdom and New York, NY, USA

41. Holton JR, Haynes PH, McIntyre ME, Douglass AR, Rood RB, Pfister L (1995) Rev Geophys 33:403-439

42. Stohl A, Bonasoni P, Cristofanelli P, Collins W et al (2003) J Geophys Res 108:8516. https://doi.org/10.1029/2002JD002490

43. Meul S, Langematz U, Kröger P, Oberländer-Hayn S, Jöckel P (2018) Atmos Chem Phys 18:7721-7738. https://doi.org/10.5194/ acp-18-7721-2018

Publisher's Note Springer Nature remains neutral with regard to jurisdictional claims in published maps and institutional affiliations. 